\title{
CORRIGENDUM
}

\section{Massive outbreak of viral gastroenteritis associated with consumption of municipal drinking water in a European capital city - CORRIGENDUM}

By D. WERBER, D. LAUŠEVIĆ, B. MUGOŠA, Z. VRATNICA, L. IVANOVIĆ-NIKOLIĆ, L. ŽIŽIĆ, A. ALEXANDRE-BIRD, L. FIORE, F. M. RUGGERI, I. DI BARTOLO, A. BATTISTONE, B. GASSILLOUD,

S. PERELLE, D. NITZAN KALUSKI, M. KIVI, R. ANDRAGHETTI AND K. G. J. POLLOCK

doi:10.1017/S095026880999015X. Published online by Cambridge University Press, 18 June 2009.

There are two statistical errors in the paper by Werber et al. (2009) regarding drinking unboiled chlorinated municipal water, for which the authors apologize:

Page 1, Summary (line 6): at the end of the line the text ' $90 \%$ (89/90)' should be replaced by ' $90 \%(80 / 89)$ '.

Page 4, 'Analytical epidemiological investigation' section (line 15): at the end of the line the text ' $80(93 \%)$ ' should be replaced by ' $80(90 \%)$ '.

\section{REFERENCE}

Werber D, et al. (2009). Massive outbreak of viral gastroenteritis associated with consumption of municipal drinking water in a European capital city. Journal of Epidemiology and Infection. Published online by the Cambridge University Press, 18 June 2009. doi:10.1017/ S095026880999015X. 